\title{
Social cognition and cortisol in the general population: A systematic review and meta-analysis
}

Running head: social cognition and cortisol

Ji, Dongying

Department of Psychology and Human Development, UCL Institute of Education, 25 Woburn Square, London WC1H OAA, UK dongying.ji@ucl.ac.uk

Flouri, Eirini

Department of Psychology and Human Development, UCL Institute of Education, 25 Woburn Square, London WC1H OAA, UK e.flouri@ucl.ac.uk

Papachristou, Efstathios

Department of Psychology and Human Development, UCL Institute of Education, 25 Woburn Square, London WC1H OAA, UK efstathios.papachristou@ucl.ac.uk

Correspondence: Dongying Ji dongying.ji@ucl.ac.uk Tel: +44(0)77 63033867

\section{Acknowledgments:}

We are grateful to the following researchers who kindly provided information regarding their relevant published studies: Daniëlle de Veld, Ulf Köther, Gillian England-Mason, Cristina Gonzalez-Liencres, Jonathan D. Lane, Wendy Kliewer, Livia Tomova, Claus Lamm, Tom Smeets, Grant Shields, Myriam Bechtoldt. This publication is the work carried out for a project funded by the UK Economic and Social Research Council (Grant ref.: ES/P001742/1; PI Eirini Flouri).

Declarations of interest: none

This article has been accepted for publication and undergone full peer review but has not been through the copyediting, typesetting, pagination and proofreading process, which may lead to differences between this version and the Version of Record. Please cite this article as doi: 10.1002/smi.3013.

This article is protected by copyright. All rights reserved. 
Title: Social cognition and cortisol in the general population: A systematic review and metaanalysis

\section{Abstract}

This systematic review examines the evidence on the association between social cognition and cortisol in the general population. Literature was searched in six databases. Of the 401 studies identified, meta-analyses were conducted on 46 effect sizes (Pearson's correlation coefficients) from 19 studies, supplemented by a narrative review. Pooled estimates suggest that better emotion control is associated with increased cortisol concentrations $[r=0.083,95 \% \mathrm{Cl}(0.033,0.132)]$. Emotion recognition or empathy were not significantly associated with cortisol concentration $[r=$ $0.072,95 \% \mathrm{Cl}(-0.020,0.165)$ and $\mathrm{r}=0.004,95 \% \mathrm{Cl}(-0.061,0.068)$ respectively]. Subgroup analyses showed that the association between emotion control and cortisol concentration is significant in males, for morning cortisol, when the cortisol data are transformed to correct for skewed distributions, and when participants are instructed to avoid food and drink intake for at least one hour before sample collection. There was no evidence for an association between social cognition with diurnal cortisol slope or cortisol awakening response. More validation work with greater standardization of methodological procedures is required.

\section{Key words}

social cognition; cortisol; emotion control; empathy; emotion recognition; general population

This article is protected by copyright. All rights reserved. 


\section{Introduction}

Social cognition refers to the mental operations that underlie social interactions and includes a variety of cognitive processes relevant to perceiving, understanding and responding to the intentions, emotions and behaviors of others (Ochsner, 2008). Happé \& Frith (2014) identified ten domains of social cognition, ranging from basic processes such as in-group/out-group categorization, emotion processing, empathy, and mental state attribution, to higher-order social processes such as social policing. All social cognition abilities facilitate healthy social interactions by helping to decode social cues and adjust behaviors accordingly (Astington, 2001). Deficits in social cognition have been linked to several adverse outcomes, such as higher stress levels and mental ill-health (Eisenberg, Eggum, \& Di Giunta, 2010; Plana et al., 2014; Rich et al., 2008). It has been suggested that such associations are in line with the social skills deficit vulnerability model, according to which those with social cognition deficits are more likely to be exposed to stressors, such as physical conflicts and social withdrawal, and less able to secure the social support necessary for dealing with the resulting stress (Knox \& Douglas, 2009; Segrin, McNelis, \& Swiatkowsk, 2016; Shakoor et al., 2012).

The main physiological mechanism responsible for eliciting and terminating both chronic and acute stress responses is the hypothalamic-pituitary-adrenal (HPA) axis. Cortisol, the key functional end product of HPA axis activity has been widely used to measure HPA-axis function. Repeated or prolonged exposure to stress contributes to hyperactivity of the HPA axis and overt cortisol excess (Miller, Chen, \& Zhou, 2007). Persistently increased cortisol secretion can damage the HPA axis function and weaken its responsiveness to further stress in the long term (Corcoran et al., 2003). This is why hypocortisolism and lower overall cortisol output have also been associated with conditions of chronic stress (Heim, Ehlert, \& Hellhammer, 2000; Karb et al., 2012; Nicolson \& van Diest, 2000). Victims of repeated bullying in the workplace, for instance, have shown reduced

This article is protected by copyright. All rights reserved. 
cortisol at awakening (Hansen et al. 2006) and a lower cortisol awakening response (CAR) (Knack, Jensen-Campbell, \& Baum, 2011).

As well as impairments in social cognition making one vulnerable to stressors, such deficits in the "key resource" in facilitating social interaction can frequently cause prolonged stress (Halbesleben et al., 2014). Individuals with maladaptive emotion processing tend to ruminate about negative experiences and to exhibit greater (Quirin, Kuhl, \& Düsing, 2011) and more prolonged (Mikolajczak et al., 2007; Vrshek-Schallhorn et al., 2018) cortisol response to laboratory-induced stressors. Further evidence comes from studies on people with autism spectrum disorder (ASD) who are typically characterized by social cognition dysfunction (Corbett et al., 2009). They have been reported to have elevated diurnal cortisol levels (Muscatello \& Corbett, 2018; Putnam et al., 2015) and slight impairments in the natural change in cortisol concentration that occurs in the first hour after waking from sleep (Hamza, Hewedi, \& Ismail, 2010).

However, findings from studies examining the association between social cognition and basal cortisol in the general population are inconsistent. While some studies found negative correlations between social cognition and cortisol at awakening (Ruiz-Robledillo \& Moya-Albiol, 2014), which were in line with what the social skills deficit vulnerability model would predict, some reported no such association (Katz et al., 2018), while others found that better social cognitive ability is associated with higher levels of cortisol at awakening, greater CAR and flatter diurnal cortisol slope (Boyer \& Nelson, 2015; Otto et al., 2018). One possible explanation for the latter pattern of results is that individuals with better social cognition are more knowledgeable about social rules and, at the same time, more sensitive to social cues. For example, Engert et al., (2014) found that people who scored higher on empathy secret more cortisol solely by observing others undergo stressful situations. Intentional suppression of emotion has also been found to be associated with heightened HPA axis activation during stressful tasks (Lam et al., 2009).

This article is protected by copyright. All rights reserved. 
There are another two reasons that might explain the discrepancies in the available literature. First, social cognition is a multifaceted construct and not all of its facets are supported by the same neural networks (Kennedy \& Adolphs, 2012). Thus, difficulties in specific social cognition domains could have impacts on cortisol secretion. For example, Bechtoldt and Schneider (2016) found a positive association of poor emotion recognition with cortisol reaction to social stressors, while for emotion management there was no association. Second, it is possible that the association between social cognition and cortisol levels is moderated by other factors. The timing of the saliva or blood sample collections, for example, is key. The diurnal pattern of cortisol secretion has two distinct phases: CAR, a short increase of cortisol after awakening, followed by a decline through the rest of the day. Cortisol concentration in the early afternoon is thought to be the average of the daily cortisol level (Halbreich et al., 1982). Considering both in tandem is important. For example, children with ASD, who generally exhibit social cognition deficits, show higher morning cortisol levels than typicallydeveloping children, but similar afternoon cortisol levels (Kidd et al., 2012). An additional source of heterogeneity in the findings may relate to the statistical treatment of cortisol concentration levels. In general population samples, endocrine time series are positively skewed, hence cortisol data should be transformed prior to being analyzed using parametric tests (Miller \& Plessow, 2013). However, not all studies have taken this into account. Additional sources of heterogeneity (and therefore potential moderators considered in this meta-analysis) include study design (crosssectional vs. longitudinal), age and sex of the participants, whether the participants had experienced childhood maltreatment, and fasting preceding sample collection (whether the participants were instructed to avoid food and drink intake at least one hour prior to the sample collection in studies analyzing blood or saliva).

To date, there has been no systematic review of the studies exploring the association between various aspects of social cognition and naturally fluctuating cortisol in the general population. We

This article is protected by copyright. All rights reserved. 
therefore conducted a systematic review on this association. An important caveat however is that, although social cognition is multifaceted, most studies have focused on emotion recognition, empathy and emotion control. Emotion recognition is the ability to recognize basic emotions in facial expressions. Empathy allows people to understand others' perspectives and mental states (cognitive empathy, also known as mentalizing) and to feel others' emotional states (affective empathy; Birnie, Spaca, \& Carlson, 2010). Emotion control concerns the ability to cognitively regulate the intensity, time-course, and valence of emotional experiences. This meta-analysis therefore focused on these three core social cognition abilities. We further investigated if the relationships between social cognition and cortisol are moderated by the following factors: timing of blood or saliva sample collection, treatment of the distribution of cortisol levels, study design (cross-sectional or longitudinal), age, sex, experience of childhood maltreatment, and fasting (whether participants were instructed to avoid food and drink intake at least one hour prior to the sample collection). For empathy, we also included type (cognitive or affective) as a potential moderator because the two components of empathy, though overlapping, engage mostly distinct neural networks (Mehta et al., 2014; Yu \& Chou, 2018). For studies that were not amenable to meta-analysis (i.e., if too few), a narrative review of their findings was conducted to synthesize the current state of knowledge.

\section{Method}

\subsection{Study selection and inclusion criteria}

\subsubsection{Literature search}

The meta-analytic process was conducted according to Preferred Reporting Items for Systematic Reviews and Meta-Analyses Protocols (PRISMA-P; Moher et al., 2015). The protocol for this review was registered with PROSPERO: International prospective register of systematic reviews

This article is protected by copyright. All rights reserved. 
CRD42019132363. Terminology was not consistent across studies. For instance, affective Theory of Mind, emotion contagion, emotional mirroring, emotion understanding, and emotional resonance all appear to refer to remarkably similar processes (Happé, Cook, \& Bird, 2017). Thus, we used broad searching terms (e.g., emot* or affective). A systematic database search was conducted on EMBASE, PsycARTICLES, PsychINFO, PubMed, ScienceDirect and Web of Science with the following terms in Title: (affective or affiliation or appraisal* or belief* or cue(s) or communication or egocentri* or empathy or emot* or face* or facial* or mirror system or mirror neuron or mood or non-verbal* or perception* or reciprocity or recognition* or regulat* or role-taking or social cognition or sociocognitive* or social-affective* or social skills or social competence or stereotyp* or theory of mind or ToM or mental* or expressive suppression or attribution bias or reciprocity), combined with the following searching terms in Title, Abstract and Keywords (hypothalamic-pituitary-adrenocortical or HPA or cortisol or glucocorticoid(s) or steroid(s)), using the Boolean operator "and". The search was restricted to articles written in English. The wildcard asterisk allowed for the inclusion of different word endings. Only papers published in peer-reviewed journals between January 1980 and March 2019 and providing sufficient statistical information to be quantitatively compared to each other were included. The corresponding authors of all relevant studies that did not provide the statistical information needed for our analyses were emailed with a request to share it. Of the 45 authors contacted (one had co-authored two articles), 9 responded. The authors who responded are listed in "Acknowledgments". A summary of the selection and exclusion criteria at each phase of screening is illustrated in Figure 1.

\subsubsection{Exclusion criteria}

This meta-analysis focuses on the relationship between core social cognition abilities and naturally occurring cortisol concentration, assayed from either cerebral spinal fluid, urine, blood, saliva, or hair, in general population samples. Studies were excluded based on the following criteria (Fig.1): (1) studies on animals; (2) reviews and not original research articles; (3) studies based on small samples

This article is protected by copyright. All rights reserved. 
$(\mathrm{N}<10)$ or case studies; (4) studies on patients with endocrine disorders and/or receiving hormonal treatment; (5) studies that included samples of patients with diagnosed mental disorders; (6) studies on infants and children younger than 3 years of age; and (7) studies measuring anticipatory cortisol response to acute laboratory-based or real-life stressors.

\subsubsection{Selected studies}

The 24 studies selected for this review used various cortisol measures. Consistent with the findings from a previous meta-analysis of studies on the link between chronic stressors and HPA functions (Miller, Chen, \& Zhou, 2007), most studies ( $n=19$ ) assessed cortisol concentrations at certain time points (morning or afternoon cortisol) and were included in the meta-analysis (Table 2). As too few studies assessed diurnal cortisol rhythm (CAR, $n=2$; diurnal cortisol slope, $n=2 ;$ both, $n=1$ ), these were synthesized narratively. Only two studies explored the relationships between social cognition and hair cortisol (Kao et al., 2019; Villanueva, Montoya-Castilla, \& Prado-Gascó, 2017), and these are reviewed in the online supplementary material.

\subsection{Calculation of effect sizes}

We chose Pearson's $r$ correlation coefficient as an indicator of effect size because it was reported in all 19 studies included in this meta-analysis. Because in some studies the variables we were interested in were reverse coded, we recoded where appropriate so that positive correlations here reflect associations between better social cognition ability and greater cortisol concentration. The guidelines that we followed regarding the calculation of effect sizes are outlined in the Table 1.

\subsection{Coding strategy}

After full-text review, we categorized studies according to three core social cognition abilities on the basis of the measures used: emotion recognition, empathy (cognitive and affective) and emotion control. Studies were coded for a range of characteristics based on a priori decisions about potential

This article is protected by copyright. All rights reserved. 
moderators. It was not possible to examine study design and maltreatment history as potential moderators because only one study used longitudinal data (Kliewer et al., 2016) and only one assessed maltreatment history (England-Mason et al., 2017). Of the potential moderators we could examine, two were dummy-coded (whether the cortisol data were transformed to correct skewed distributions, and whether participants were instructed to avoid food and drink intake at least one hour preceding sample collection). Sampling time and sex of the participants were contrast-coded, because none of the three groups (morning, early afternoon, and non-specific time; males, females, and both) could suitably serve as a reference category for the remaining ones. The average age of participants was coded into four categories: children (younger than 10 years), adolescents (from 10 to 18 years), young adults (from 18 to 30 years) and middle-aged and older adults (older than 30 years). If the average participant age was not reported in the article, the median age was used when available. If that was not available either, the midpoint of the reported age range was used. For empathy specifically, type (cognitive or affective) was also explored as a potential moderator. In the studies we examined, false-belief tasks such as the unexpected-contents task (Perner, Leekam, \& Wimmer, 1987) and the switched-location task (Wimmer \& Perner, 1983) are widely used to test cognitive empathy. The Interpersonal Reactivity Index (IRI; Davis, 1983) is used to test both cognitive and affective empathy (Table 2).

\subsection{Analytic strategy}

Psychometric meta-analysis was employed to estimate pooled effect sizes across studies (Hunter \& Schmidt, 2004). This is a random-effects model that accounts for dependence between effect sizes and generates more accurate confidence intervals compared to the fixed-model approach (Schmidt, Oh, \& Hayes, 2009). Following the suggestions of Schmidt and Hunter (2015), we corrected for sampling bias by weighting effects by the size of the samples, and for measurement error (only for studies using scales or questionnaires to measure social cognition; for studies using experimental tasks (e.g., the Reading the Mind in the Eyes Test; Baron-Cohen et al., 2001) to measure it, we

This article is protected by copyright. All rights reserved. 
respected the values reported) by using the reliability coefficients of the measures. Both mean observed correlations $(\bar{r})$ and mean corrected correlations $(\rho)$ were computed, as well as confidence intervals (Cls) around the mean corrected correlations. As suggested by Cohen (1988), $\rho$ of less than 0.2 were interpreted as "small", those larger than 0.37 as "large", and those in between as "moderate". Forest plots were created to illustrate the corrected effect sizes for each study included in the meta-analysis, as well as the pooled effect size, with associated $95 \% \mathrm{Cls}$.

After calculating pooled effect sizes, the heterogeneity among individual effect sizes was assessed by means of Cochrane's $Q$ and $I^{2}$ statistics. The Cochrane's $Q$ is a measure of the weighted squared deviations of individual effect sizes from the overall mean effect size, indicating the total amount of observed variance (Lipsey \& Wilson, 2001). $I^{2}$ represents the percentage of observed variation that is attributable to heterogeneity rather than within-study sampling error. $I^{2}$ values between 0.3-0.6 are considered to represent moderate heterogeneity, and 0.5-0.9 substantial (Higgins \& Green, 2008). First, we examined whether there was significant heterogeneity between studies measuring each of the three core social cognition domains. Subgroup analysis was then performed to estimate the average effect size within each level of the moderating variable.

To test for publication bias, funnel plots of effect sizes against their standard errors were generated. Asymmetry in funnel plots is indicative of presence of publication bias (Sterne, Egger, \& Moher, 2008). Egger's tests were used to formally test for the asymmetry of the funnel plot (Egger et al., 1997). We used the "psychmeta" (Dahlke \& Wiernik, 2018, version 2.2.0) package to conduct the analyses and "forestplot" package (Gordon, 2016) to create forest plots in R (R core team, 2019, version 3.6.1).

\section{Results}

This article is protected by copyright. All rights reserved. 


\subsection{Quantitative synthesis: meta-analyses}

The meta-analysis used 19 studies (Table 2) examining social cognition in relation to cortisol concentration, reporting 46 effect sizes in total. In particular, there were 16 effect sizes ( $k=11$ studies) for emotion control, 20 ( $k=10$ studies) for empathy and 10 ( $k=6$ studies) for emotion recognition (total number of studies is not 27 as it may appear because studies are not mutually exclusive).

\subsubsection{Emotion control}

We found 11 studies examining emotion control in relation to cortisol concentration (Bechtoldt \& Schneider, 2016; Brandtstädter et al., 1991; England-Mason et al., 2017; Fox, Cahill, \& Zougkou, 2010; Kliewer et al., 2016; Locke et al., 2009; Mikolajczak et al., 2007; Miller et al., 2017; Shields et al., 2016; van Honk et al., 2000; Wilbraham, Qualter, \& Roy, 2018; Table 2). As shown in Figure 2, effect sizes for the association between emotion control and cortisol levels ranged from -0.070 to 0.270 , with a weighted average effect size of $r=0.083,95 \% \mathrm{Cl}(0.033,0.132]$, suggesting that higher emotion control scores are significantly linked to higher cortisol levels. Homogeneity of findings between studies was confirmed, Cochrane $Q(10)=11.134, p=.347,1^{2}=10.2 \%$. Neither inspection of the funnel plots nor Egger's tests showed any evidence of publication bias [Egger's test: intercept = $0.320 ; 95 \% \mathrm{Cl}(-1.280,1.920) ; \mathrm{t}(10)=0.45, p=.662 ;$ Figure 5$)$.

Next, we examined the weighted average correlation separately for the different levels of potential moderators (Table 3). We observed a significant positive effect size in studies measuring cortisol in the morning $[r=0.085,95 \% \mathrm{Cl}(0.006,0.164)]$, but not in studies measuring cortisol at noon or in the afternoon $[r=0.025,95 \% \mathrm{Cl}(-0.041,0.092)]$. We also found a significant positive correlation between emotion control and cortisol levels in males $[r=0.086,95 \% \mathrm{Cl}(0.007,0.164)]$, but not in

This article is protected by copyright. All rights reserved. 
females $[r=0.070,95 \% \mathrm{Cl}(-0.068,0.209)]$. In terms of the studies using transformed cortisol data [of those that did, Wilbraham et al.'s (2018) used square-root-transformation while the others applied log-transformation], the average effect size was significant $[r=0.086,95 \% \mathrm{Cl}(0.034,0.137)]$. The association was not significant in the studies not using data transformation $[r=0.039,95 \% \mathrm{Cl}$ ($0.451,0.529)]$, and heterogeneity was noticeable $[Q(4)=3.817, p>.05,12=47.6 \%]$. For studies instructing participants to fast before sample collection, improved emotion control was significantly associated with higher cortisol levels, with trivial heterogeneity $[r=0.119,95 \% \mathrm{Cl}(0.013,0.224)$; $\mathrm{C}$ $\left.(4)=4.896, p>.05, l^{2}=18.3 \%\right]$. However, for studies that did not report issuing fasting instructions preceding sample collection, the effect size was not significant $[r=0.061,95 \% \mathrm{Cl}(-0.005,0.127)]$. The weighted average correlation between emotion control and cortisol levels was $0.121[95 \% \mathrm{Cl}$ $(0.022,0.220)]$ in children, $0.145[95 \% \mathrm{Cl}(-0.753,1.04)]$ in adolescents, $0.038[95 \% \mathrm{Cl}(-0.074,0.150)]$ in young adults and $0.052[95 \% \mathrm{Cl}(0.003,0.100)]$ in older adults. It must be noted however that only one and two studies, respectively, were included in the two subgroups showing significant results (i.e., children and older adults).

\subsubsection{Empathy}

We found 10 studies examining empathy in relation to cortisol concentration (Bechtoldt \& Schneider, 2016; Gonzalez-Liencres et al., 2016; Lane et al., 2013; Mikolajczak et al., 2007; Oberle, 2018; Pascual-Sagastizabal et al., 2019; Smeets et al., 2009; Tomova et al., 2014; Wilbraham, Qualter, \& Roy, 2018; Zilioli, Ponzi, \& Henry, 2015; Table 2). As shown in Figure 3, effect sizes for the association between empathy and cortisol levels ranged from -0.116 to 0.257 , with a weighted average effect size of $r=0.072,95 \% \mathrm{Cl}(-0.020,0.165)$. The $\mathrm{Cl}$ suggests that empathy scores are not significantly associated with cortisol levels, although substantial heterogeneity was detected [Cochrane $Q(9)=19.870, p=0.019 ; l^{2}=54.7 \%$ ]. However, the pooled effect sizes for all subgroups

This article is protected by copyright. All rights reserved. 
were not statistically significant. Neither visual inspection of the funnel plots nor Egger's test showed any evidence of publication bias [intercept $=-1.591 ; 95 \% \mathrm{Cl}(-4.362,1.181), \mathrm{t}(9)=-1.32, p=.222$ ].

\subsubsection{Emotion recognition}

We found 6 studies examining emotion recognition in relation to cortisol concentrations] (Bechtoldt \& Schneider, 2016; Köther, Lincoin, \& Moritz, 2018; Smeets et al., 2009; Tomova et al., 2014; Wilbraham, Qualter, \& Roy, 2018; Zilioli, Ponzi, \& Henry, 2015; Table 2). As shown in Figure 4, effect sizes for the association between emotion recognition and cortisol levels ranged from -0.115 to 0.045. The weighted average effect size was not significant, $r=0.004,95 \% \mathrm{Cl}(-0.061,0.068)$. There was negligible heterogeneity, $Q(5)=2.673, p=.750, l^{2}=0 \%$, indicating that effect sizes were consistent between studies, and subgroup analyses revealed no significant result for any of the subgroups. Neither visual inspection of the funnel plots nor Egger's test showed any evidence of publication bias [intercept $=-0.936 ; 95 \% \mathrm{Cl}(-2.522,0.649) ; \mathrm{t}(5)=-1.64, p=.177]$.

\subsection{Narrative synthesis}

Five studies examined the relationships between social cognition and diurnal cortisol rhythm (CAR or diurnal cortisol slope) in the general population (Table 4). Four of them focused on emotion control (Katz et al., 2018; Locke et al., 2009; Miller et al., 2017; Otto, Sin, \& Almeida, 2018), and one on empathy (Johnson et al., 2014). The results of these studies were inconsistent. Two studies found no association between emotion control and CAR (Miller et al., 2017) or diurnal cortisol slope (Katz et al., 2018). In the two studies with significant findings, poor emotion control was linked to lower CAR (Otto, Sin \& Almeida, 2018) and a flatter diurnal slope (Locke et al, 2009). However, Otto, Sin and Almeida (2018) reported a notable, albeit non-significant, link between poor emotion control and

This article is protected by copyright. All rights reserved. 
steeper diurnal slope. The study on empathy suggested that greater CAR was related to affective empathy but not cognitive empathy (Johnson et al., 2014).

Heterogeneity in study design, developmental stage of the sample and treatment of confounding was considerable across the reviewed studies, which may partly explain the inconsistent findings. For example, one study controlled for a variety of demographic variables that might influence diurnal cortisol, such as age, sex, race, smoking, illness, BMI and steroidal medication use (i.e. Otto, Sin \& Almeida, 2018), while another only considered one or a few of them (i.e. Johnson et al., 2014). The association between emotion control and flattened diurnal slope was marginally positive in adults (Otto, Sin \& Almeida, 2018), but was significantly negative in children (Locke et al, 2009). In addition, moderator effects were inconsistently tested. For example, Locke et al. (2009) found moderation by sex, such that boys with poorer emotion control exhibited flatter diurnal slope. Moderation by sex was not tested however in the other study exploring the link between diurnal slope and emotion control (i.e. Otto, Sin \& Almeida, 2018).

\section{Discussion}

We carried out the first comprehensive systematic review and meta-analysis of studies examining the associations between core social cognition abilities and cortisol in the general population. The studies we included focused on three core social cognition abilities: emotion recognition, empathy

and emotion control. Contrary to our expectations, we did not find a significant association between cortisol concentration and empathy or emotion recognition. The pooled effect size for emotion control however was positive, and results were largely homogeneous. Effect sizes were, in general, small in magnitude, which is line with the magnitude of the associations between psychosocial factors and cortisol in naturalistic settings reported elsewhere (Chida \& Steptoe, 2009). The findings

This article is protected by copyright. All rights reserved. 
of the very few studies on the relationship between social cognition and diurnal cortisol rhythm were inconsistent and there was substantial heterogeneity across the studies that produced them.

One possible explanation for the positive correlation between emotion control and cortisol concentration is that emotion regulation, including suppression and inhibition of emotional expression (i.e., 'emotion control'), is cognitively effortful and therefore physically taxing (Otto et al, 2018; Richards \& Gross, 1999). Experimental research has demonstrated a link between voluntary emotion suppression and heightened physiological responses, such as increased cardiovascular or sympathetic nervous system activity (Egloff et al., 2006; Gross \& Levenson, 1993), and greater adrenocorticotropic hormone and cortisol reaction to laboratory-induced stressors (Al'Absi et al., 1997; Denson et al., 2014; Denson, Spanovic, \& Miller, 2009; Lam et al., 2009). By contrast, emotion recognition and empathy are more automatic and less effortful cognitive processes (Happé, \& Frith, 2014).

Thus, our findings did not support our expectation that better social cognition would be negatively associated with cortisol concentration. This expectation was partly built on results from studies on people with schizophrenia and autism spectrum disorder who exhibit atypical social cognition and cortisol profiles. Another explanation for the positive correlation with emotion control is therefore that the relationship between social cognition and cortisol may be different in people with serious social cognition deficits compared to the general population. Social cognition may function as a "key resource" for clinical groups having difficulties with social interactions, by reducing social stress. For the general population however, where social skills would not be severely impaired, emotion control, may come at a cost and add physical stress on the body (Richards \& Gross, 1999). Of course, as the relationship between cortisol levels and emotion control was cross-sectional, an alternative hypothesis could be that higher levels of cortisol result in better social cognition (Putman \& Roelofs, 2011). A recent review suggests that stress-related changes in the HPA may lead to self-regulation

This article is protected by copyright. All rights reserved. 
difficulties through persistent immune system dysregulation (Shields, Moons, \& Slavich, 2017).

However, one placebo-controlled, double-blind study did not find evidence that cortisol

administration can enhance the three aspects of social cognition examined here in healthy

individuals (Duesenberg et al., 2016; Ma et al., 2017), indicating that it is more plausible that better emotion control may raise cortisol levels than vice versa.

\subsection{Moderators in the meta-analysis}

Our moderation (subgroup) analyses for the association between cortisol concentration and each of emotion control, empathy and emotion recognition yielded inconsistent findings. Significant findings were observed only for the association between cortisol and emotion control. First, there was a significant positive effect size in studies sampling cortisol in the morning, but not in studies sampling cortisol in the (after)noon or when the timing of the sample collection was not specified, which indicates that people with poor emotion control have lower cortisol levels in the morning. To the extent that poor emotion control may generate psychosocial stressors and be a source of chronic stress, this may be explained by the hypocortisolism (Heim, Ehlert, \& Hellhammer, 2000; Gunnar \& Vazquez, 2001) observed under chronic stress, when individuals can transition from hypercortisolism to hypocortisolism (Koss \& Gunnar, 2018). Indeed, several studies have documented flatter daytime slopes in children who had experienced mild to severe stressors because of lower morning cortisol levels, which can be a result of chronic stress (Fries et al., 2005). Relatedly, Trickett and colleagues (2010) found that cortisol levels of maltreated females were initially higher than those of nonmaltreated females, but became lower in adulthood. To react to instant stressors, the HPA axis adapts as a protective response by elevated production of cortisol and other related hormones (i.e., adrenocorticotropic hormone). However, in the long run the receptors of these hormones may be down-regulated as a response to elevated levels of them, resulting in lower cortisol production (Fries et al., 2005). Poor emotion control may generate psychosocial stressors and be a source of chronic

This article is protected by copyright. All rights reserved. 
stress (or indeed poor emotion control may be the result of exposure to chronic stressors), further leading to hypocortisolism. However, because of lack of longitudinal data, this hypothesis could not be tested here.

The finding of a significant positive association between emotion control and cortisol levels in males was unexpected. It is not clear why emotion control was not related to cortisol levels in females or in mixed-sex groups. We speculate that biological explanations about sex differences are plausible but also that gender roles and gender socialization may make emotion control more effortful in males (Barnett \& Hyde, 2001; Mccann, Stewin, \& Short, 1991). We also observed a significant positive effect size in studies transforming their cortisol data. Wilbraham and colleagues (2018) used squareroot-transformation, Pascual-Sagastizabal and colleagues (2019) used Blom transformation while others applied log-transformation. Because most of studies used log-transformation, we cannot compare between ways of transforming the data. In agreement with Miller and Plessow's (2013) suggestion, we encourage the use of transformed data and advise care with the selection of the transformation method.

We also found a significant positive effect size in studies reporting fasting instructions preceding the sample collection. Consumption of food can cause variability in salivary cortisol levels as it can alter the oral environment and affect the quality of salivary samples (Hanrahan et al., 2006). Some drinks and foods may affect salivary $\mathrm{pH}$, leading to false high or low levels (Schwartz, Granger, Susman, Gunnar, \& Laird, 1998). In addition, a variety of foods and drinks contain caffeine which may increase HPA axis activity (Ping et al., 2012). Thus, we suggest that in the future researchers ask participants to avoid food and drink intake at least one hour prior to the collection of salivary cortisol samples.

This article is protected by copyright. All rights reserved. 
Unfortunately, there was not enough evidence to examine moderation by age. The only study on children showed a positive link between emotion control and cortisol (Miller et al., 2017). It is possible that the immaturity of the HPA axis in children and adolescents results in greater cortisol secretion and longer recovery time from exposure to stressors. Studies with animals have shown similar findings; pre-pubertal rats have a more prolonged, stress-induced corticosterone response compared to adult rats (Holder \& Blaustein, 2014; Romeo, Lee, \& McEwen, 2004). A previous study on young adolescents' diurnal cortisol profiles in relation to their social competence also showed that poorer emotion control was linked to lower cortisol concentration at awakening and a more blunted diurnal slope (Jiang et al., 2018). Yet in this meta-analysis the studies on adolescents did not yield a significant effect size. Only a small number of studies on children or adolescents were included in this meta-analysis, however, and therefore our null findings may be due to lack of power. The middle aged and older-adult group (two studies) showed significant pooled effect sizes although each study reported non-significant findings. We suggest that age differences are worth exploring systematically in future studies linking social cognition to stress.

\subsection{Future directions}

The current review contributes to the existing literature on social cognition and cortisol concentration by suggesting that one particular aspect of social cognition, emotion control, is positively associated with cortisol concentrations in the general population. However, the causal direction of the link is unknown. There are theories suggesting effects in both directions. For example, social stress may reduce attention to social cues, and may therefore worsen social cognition (Nolte et al., 2013). At the same time, poor social cognition may not arouse enough cognitive and physical response to cope with stress (Otto et al, 2018). Longitudinally designed studies tracking both social cognition and HPA activity over time are in order. The very few longitudinal studies conducted to date report mixed findings. One study indicated that increased

This article is protected by copyright. All rights reserved. 
social competence at age 7 and age 12 was associated with higher cortisol at awakening at age 15

(Boyer \& Nelson, 2015). A more recent study on emotion regulation on adults suggested that emotional suppression was not significantly associated with changes in cortisol secretion over a year (Katz et al., 2018).

Furthermore, despite rhythm parameters of salivary cortisol being most robustly linked to stress and health problems (Adam \& Kumari, 2009; Adam et al., 2017), only about a third of our studies had measured either CAR or diurnal cortisol slope. Most of the studies we identified (and indeed all of the ones we included in the meta-analysis) had only measured cortisol concentration at a time of day. Whilst cortisol concentration is useful in exploring between-group differences, it is difficult to interpret its meaning without a co-measure of diurnal rhythm. As discussed above, both hypocortisolism and hypercortisolism have been related to chronic stress, and therefore the amount of cortisol at a fixed time, especially without detailed life history information, can only crudely approximate stress in the general population. Therefore, more research on the relationship between social cognition and all three key cortisol rhythm parameters (CAR, diurnal slope and AUC) is required.

In addition, the effects of cortisol in this meta-analysis were considered in isolation, whereas typically cortisol exerts its effects alongside reactivity in catecholamines, the sympathetic nervous system, and the immune system (Hall et al., 2012). Hence, other biological processes or hormones may influence the relationship between social cognition abilities and cortisol. For example, there is increasing support for the involvement of testosterone in the relationship between social cognition and cortisol in older adolescents or adults. Bechtoldt and Schneider (2016) for instance found moderating effects of testosterone on the interplay between emotion recognition and stress reactivity on young adults. In their study, better recognition of negative emotions predicted higher

This article is protected by copyright. All rights reserved. 
cortisol response to social-evaluation stressors at high concentrations of basal testosterone.

However, this dual-hormone hypothesis to emotion recognition, or indeed social cognition in general, has not been tested in naturalistic settings. Testosterone and cortisol are also inter-related. Testosterone is the product of the hypothalamic-pituitary gonadal (HPG) axis, which is co-regulated with the HPA axis. Testosterone can inhibit the release of cortisol, while cortisol can inhibit the secretion of testosterone (Viau, 2002).

Finally, the correlation between social cognition and cortisol levels may turn to negative in a longterm highly stressful environment, when social cognition might function as "key resource" to coping with stress. Ruiz-Robledillo and Moya-Albiol (2014) showed that better emotion control was related to a lower morning cortisol profile in caregivers of children with autism spectrum disorder. Extreme adversity can have a similar long-term effect. For example, childhood maltreatment can cause longterm stress and has been demonstrated to contribute to chronic hypocortisolemia in adults (Kuras et al., 2017). It can also be related to social cognition deficits. Koizumi and Takagishi (2014) studied 129 children and adolescents (age 6 to 19 years) and found that those with a maltreatment history showed worse emotion recognition, especially for positive emotions, compared with those without a maltreatment history. However, because our review only included studies in the general population, we could not explore the effect of adversity on the relationship between social cognition abilities and cortisol or HPA function. Future research should attempt to examine how early adversity or major life stressors might affect this relationship.

\subsection{Limitations}

This meta-analysis has several limitations too. First, the studies showed substantial heterogeneity. Social cognition is a multifaceted construct but in this review we could only explore three of its aspects, and they were not measured with the same instruments. For instance, four of the included

This article is protected by copyright. All rights reserved. 
studies used the Reading the Mind in the Eyes Test (Baron-Cohen et al. 2001) to measure emotion recognition, while others used emotional intelligence scales (e.g. Mayer-Salovey-Caruso Emotional Intelligence Test; Mayer et al., 2003). This could be a potential source of the heterogeneity observed. Second, we only had 19 studies with a total of 46 effect sizes, with even fewer effect sizes when subgroup analysis was conducted. Therefore lack of power to detect small effects is likely. Third, since we had to rely on secondary data, the exact sampling time of cortisol in the morning could not be obtained for every study included in our review. The range of time of collection spanned from 8:30 a.m. to 12 p.m., a time window too wide to capture the same point in the circadian rhythm of cortisol for everyone in every study. Fourth, this meta-analysis could not assess potential differences pertaining to the type of sample collected, e.g. urine, blood and hair, due to insufficient numbers of studies available. Fifth, variables that may be relevant to the relationship between cortisol levels and social cognition, such as childhood maltreatment, mental illness history and genetic vulnerability, were not available.

\section{Conclusion}

This review examined the relationship, in the general population, between cortisol concentrations and three core aspects of social cognition: emotion recognition, empathy and emotion regulation. The meta-analysis found that better emotion control was associated with higher cortisol concentrations. Subgroup analysis further showed that this association was significant for morning cortisol, in males, when fasting instructions preceding cortisol sampling were issued, and when the cortisol data were transformed in the analysis to deal with the skewness of the data distribution. There was no association between emotion recognition or empathy and cortisol levels. There was not enough evidence to suggest a link between social cognition and diurnal cortisol slope or cortisol awakening response.

This article is protected by copyright. All rights reserved. 


\section{Acknowledgments}

We are grateful to the following researchers who kindly provided information regarding their relevant published studies: Daniëlle de Veld, Ulf Köther, Gillian England-Mason, Cristina GonzalezLiencres, Jonathan D. Lane, Wendy Kliewer, Livia Tomova, Claus Lamm, Tom Smeets, Grant Shields, Myriam Bechtoldt. This publication is the work carried out for a project funded by the UK Economic and Social Research Council (Grant ref.: ES/P001742/1; PI Eirini Flouri). We report no biomedical financial interests or potential conflicts of interest.

This article is protected by copyright. All rights reserved. 
References (* are studies included in the meta-analysis)

Adam, E. K., \& Kumari, M. (2009). Assessing salivary cortisol in large-scale, epidemiological research. Psychoneuroendocrinology, 34(10), 1423-1436. https://doi.org/10.1016/j.psyneuen.2009.06.011

Adam, E. K., Quinn, M. E., Tavernier, R., McQuillan, M. T., Dahlke, K. A., \& Gilbert, K. E. (2017). Diurnal cortisol slopes and mental and physical health outcomes: A systematic review and meta-analysis. Psychoneuroendocrinology, 83, 25-41. https://doi.org/10.1016/j.psyneuen.2017.05.018

Al'Absi, M., Bongard, S., Buchanan, T., Pincomb, G.A., Licinio, J., Lovallo, W.R., 1997. Cardiovascular and neuroendocrine adjustment to public speaking and mental arithmetic stressors. Psychophysiology 34, 266-275. https://doi.org/10.1111/j.1469-8986.1997.tb02397.x

Astington, J. W. (2001). The future of theory-of-mind research: Understanding motivational states, the role of language, and real-world consequences. Child development, 72(3), 685-687. https://doi.org/10.1177/014662168400800407

Barnett, R. C., \& Hyde, J. S. (2001). Women, men, work, and family: An expansionist theory. American psychologist, 56(10), 781. https://psycnet.apa.org/doi/10.1037/0003-066X.56.10.781

Baron-Cohen, S., Wheelwright, S., Hill, J., Raste, Y., \& Plumb, I. (2001). The "Reading the Mind in the Eyes" Test revised version: a study with normal adults, and adults with Asperger syndrome or highfunctioning autism. The Journal of Child Psychology and Psychiatry and Allied Disciplines, 42(2), 241-251. https://psycnet.apa.org/doi/10.1111/1469-7610.00715

*Bechtoldt, M. N., \& Schneider, V. K. (2016). Predicting stress from the ability to eavesdrop on feelings: Emotional intelligence and testosterone jointly predict cortisol reactivity. Emotion, 16(6), 815825. https://psycnet.apa.org/doi/10.1037/emo0000134

Birnie, K., Speca, M., \& Carlson, L. E. (2010). Exploring self-compassion and empathy in the context of mindfulness-based stress reduction (MBSR). Stress and Health, 26(5), 359-371. https://doi.org/10.1002/smi.1305

Boyer, B. P., \& Nelson, J. A. (2015). Longitudinal associations of childhood parenting and adolescent health: the mediating influence of social competence. Child Development, 86(3), 828-843. https://doi.org/10.1111/cdev.12347

*Brandtstädter, J., Baltes-Götz, B., Kirschbaum, C., \& Hellhammer, D. (1991). Developmental and personality correlates of adrenocortical activity as indexed by salivary cortisol: observations in the age range of 35 to 65 years. Journal of Psychosomatic Research, 35(2-3), 173-185. https://doi.org/10.1016/0022-3999(91)90072-v

Chida, Y., \& Steptoe, A. (2009). Cortisol awakening response and psychosocial factors: a systematic review and meta-analysis. Biological psychology, 80(3), 265-278. https://doi.org/10.1016/00223999\%2891\%2990072-V

Cohen, J. (1988). Statistical power analysis for the behavioral sciences (2nd ed.). Hillsdale, NJ: Lawrence Earlbaum Associates.

Corbett, B. A., Schupp, C. W., Levine, S., \& Mendoza, S. (2009). Comparing cortisol, stress, and sensory sensitivity in children with autism. Autism Research: Official Journal of the International Society for Autism Research, 2(1), 39-49. https://doi.org/10.1002/aur.64

This article is protected by copyright. All rights reserved. 
Corcoran, C., Walker, E., Huot, R., Mittal, V., Tessner, K., Kestler, L., \& Malaspina, D. (2003). The stress cascade and schizophrenia: etiology and onset. Schizophrenia bulletin, 29(4), 671-692. https://doi.org/10.1093/oxfordjournals.schbul.a007038

Dahlke, J. A., \& Wiernik, B. M. (2018). psychmeta: An R package for psychometric meta-analysis. Applied Psychological Measurement, 0146621618795933. https://doi.org/10.1177/0146621618795933

Davis, M. H. (1983). Measuring individual differences in empathy: Evidence for a multidimensional approach. Journal of personality and social psychology, 44(1), 113. https://doi.org/10.1037/00223514.44.1.113

Denson, T. F., Creswell, J. D., Terides, M. D., \& Blundell, K. (2014). Cognitive reappraisal increases neuroendocrine reactivity to acute social stress and physical pain. Psychoneuroendocrinology, 49, 69-78. https://doi.org/10.1016/j.psyneuen.2014.07.003

Denson, T. F., Spanovic, M., \& Miller, N. (2009). Cognitive appraisals and emotions predict cortisol and immune responses: a meta-analysis of acute laboratory social stressors and emotion inductions. Psychological bulletin, 135(6), 823. https://psycnet.apa.org/doi/10.1037/a0016909

Doherty, R. W. (1997). The emotional contagion scale: A measure of individual differences. Journal of Nonverbal Behavior, 21(2), 131-154. https://doi.org/10.1023/A:1024956003661

Duesenberg, M., Weber, J., Schulze, L., Schaeuffele, C., Roepke, S., Hellmann-Regen, J., ... Wingenfeld, K. (2016). Does cortisol modulate emotion recognition and empathy? Psychoneuroendocrinology, 66, 221-227. https://doi.org/10.1016/j.psyneuen.2016.01.011

Dziobek, I., Fleck, S., Kalbe, E., Rogers, K., Hassenstab, J., Brand, M., ... \& Convit, A. (2006). Introducing MASC: a movie for the assessment of social cognition. Journal of autism and developmental disorders, 36(5), 623-636. https://doi.org/10.1007/s10803-006-0107-0

Eisenberg, N., Eggum, N. D., \& Di Giunta, L. (2010). Empathy-related responding: Associations with prosocial behavior, aggression, and intergroup relations. Social issues and policy review, 4(1), 143-180. https://doi.org/10.1111/j.1751-2409.2010.01020.x

Egger, M., Smith, G. D., Schneider, M., \& Minder, C. (1997). Bias in meta-analysis detected by a simple, graphical test. Bmj, 315(7109), 629-634. https://doi.org/10.1136/bmj.315.7109.629

Egloff, B., Schmukle, S. C., Burns, L. R., \& Schwerdtfeger, A. (2006). Spontaneous emotion regulation during evaluated speaking tasks: Associations with negative affect, anxiety expression, memory, and physiological responding. Emotion, 6(3), 356-366. https://doi.org/10.1037/1528-

3542.6.3.356

Ekman, P., \& Friesen, W.V., (1976). Pictures of facial affect. Palo Alto, California: Consulting Psychologists Press

Engert, V., Plessow, F., Miller, R., Kirschbaum, C., \& Singer, T. (2014). Cortisol increase in empathic stress is modulated by emotional closeness and observation modality. Psychoneuroendocrinology, 45, 192-201. https://doi.org/10.1016/j.psyneuen.2014.04.005

*England-Mason, G., Kimber, M., Khoury, J., Atkinson, L., MacMillan, H., \& Gonzalez, A. (2017). Difficulties with emotion regulation moderate the association between childhood history of maltreatment and cortisol reactivity to psychosocial challenge in postpartum women. Hormones and Behavior, 95, 44-56. https://doi.org/10.1016/j.yhbeh.2017.07.007

This article is protected by copyright. All rights reserved. 
Fahrenbekc, J., Hampel, R., \& Selg H. (1973). Freiburg Personality Inventory. Second Ed. Gottingen: Hogrefe.

Fries, E., Hesse, J., Hellhammer, J., \& Hellhammer, D. H. (2005). A new view on hypocortisolism. Psychoneuroendocrinology, 30(10), 1010-1016. https://doi.org/10.1016/j.psyneuen.2005.04.006

*Fox, E., Cahill, S., \& Zougkou, K. (2010). Preconscious processing biases predict emotional reactivity to stress. Biological Psychiatry, 67(4), 371-377. https://doi.org/10.1016/j.biopsych.2009.11.018

*Gonzalez-Liencres, C., Breidenstein, A., Wolf, O. T., \& Brüne, M. (2016). Sex-dependent effects of stress on brain correlates to empathy for pain. International Journal of Psychophysiology, 105, 47-56. https://doi.org/10.1016/j.ijpsycho.2016.04.011

Gordon, M. (2016) Package 'forestplot'. Advanced Forest Plot Using 'grid' Graphics.

Gratz, K. L., \& Roemer, L. (2004). Multidimensional assessment of emotion regulation and dysregulation: Development, factor structure, and initial validation of the difficulties in emotion regulation scale. Journal of psychopathology and behavioral assessment, 26(1), 41-

54. https://doi.org/10.1023/B:JOBA.0000007455.08539.94

Gross, J.J., \& John, O. P. (2003). Individual differences in two emotion regulation processes: Implications for affect, relationships, and well-being. Journal of Personality and Social Psychology, 85, 348362. https://doi.org/10.1037/0022-3514.85.2.348

Gross, J. J., \& Levenson, R. W. (1993). Emotional suppression: Physiology, self-report, and expressive behavior. Journal of Personality and Social Psychology, 64(6), 970986. https://doi.org/10.1037/0022-3514.64.6.970

Gunnar, M. R., \& Vazquez, D. M. (2001). Low cortisol and a flattening of expected daytime rhythm: Potential indices of risk in human development. Development and psychopathology, 13(3), 515538. https://doi.org/10.1017/s0954579401003066

Halbesleben, J. R. B., Neveu, J.-P., Paustian-Underdahl, S. C., \& Westman, M. (2014). Getting to the "COR": Understanding the role of resources in conservation of resources theory. Journal of Management, 40, 1334-1364. https://doi.org/10.1177/0149206314527130

Halbreich, U., Zumoff, B., Kream, J., \& Fukushima, D. K. (1982). The mean 1300-1600 h plasma cortisol concentration as a diagnostic test for hypercortisolism. The Journal of Clinical Endocrinology \& Metabolism, 54(6), 1262-1264. https://doi.org/10.1210/jcem-54-6-1262

Hall, J. M., Podawiltz, A., Mummert, D. I., Jones, H., \& Mummert, M. E. (2012). Psychological stress and the cutaneous immune response: roles of the HPA axis and the sympathetic nervous system in atopic dermatitis and psoriasis. Dermatology research and practice, 2012. https://doi.org/10.1155/2012/403908

Hamza, R. T., Hewedi, D. H., \& Ismail, M. A. (2010). Basal and adrenocorticotropic hormone stimulated plasma cortisol levels among Egyptian autistic children: relation to disease severity. Italian journal of pediatrics, 36(1), 71. https://doi.org/10.1186/1824-7288-36-71

Hanrahan, K., McCarthy, A. M., Kleiber, C., Lutgendorf, S., \& Tsalikian, E. (2006). Strategies for salivary cortisol collection and analysis in research with children. Applied Nursing Research, 19(2), 95-101. https://doi.org/10.1016/j.apnr.2006.02.001

This article is protected by copyright. All rights reserved. 
Happé, F., \& Frith, U. (2014). Annual research review: Towards a developmental neuroscience of atypical social cognition. Journal of Child Psychology and Psychiatry, 55(6), 553-577.

https://doi.org/10.1111/jcpp.12162

Happé, F., Cook, J. L., \& Bird, G. (2017). The structure of social cognition: In (ter) dependence of sociocognitive processes. Annual review of psychology, 68, 243-267. https://doi.org/10.1146/annurev-psych-010416-044046

Heim, C., Ehlert, U., \& Hellhammer, D. H. (2000). The potential role of hypocortisolism in the pathophysiology of stress-related bodily disorders. Psychoneuroendocrinology, 25(1), 1-35. https://doi.org/10.1016/S0306-4530(99)00035-9

Hansen, Å. M., Hogh, A., Persson, R., Karlson, B., Garde, A. H., \& Ørbaek, P. (2006). Bullying at work, health outcomes, and physiological stress response. Journal of psychosomatic research, 60(1), 6372. https://doi.org/10.1016/j.jpsychores.2005.06.078

Higgins, J. P., \& Green, S. (2008). Defining the review question and developing criteria for including studies. In Cochrane handbook for systematic reviews of interventions (Vol. 1, p. 83). https://doi.org/10.1002/9780470712184.ch5

Holder, M. K., \& Blaustein, J. D. (2014). Puberty and adolescence as a time of vulnerability to stressors that alter neurobehavioral processes. Frontiers in neuroendocrinology, 35(1), 89-110. https://doi.org/10.1016/j.yfrne.2013.10.004

Hunter, J. E., \& Schmidt, F. L. (2004). Methods of meta-analysis: Correcting error and bias in research findings (2nd ed.). Newbury Park: Sage

Jiang, Y., Li, X., Chen, L., Zhou, G., Zhao, J., \& Zhao, G. (2018). Peer victimization and diurnal cortisol rhythm among children affected by parental HIV: Mediating effects of emotional regulation and gender differences. Psychoneuroendocrinology, 97, 174-181.

https://doi.org/10.1016/j.psyneuen.2018.07.010

Johnson, M. M., Caron, K. M., Mikolajewski, A. J., Shirtcliff, E. A., Eckel, L. A., \& Taylor, J. (2014). Psychopathic traits, empathy, and aggression are differentially related to cortisol awakening response. Journal of Psychopathology and Behavioral Assessment, 36(3), 380-388. https://doi.org/10.1007/s10862-014-9412-7

Kao, K., Tuladhar, C. T., Meyer, J. S., \& Tarullo, A. R. (2019). Emotion regulation moderates the association between parent and child hair cortisol concentrations. Developmental Psychobiology. https://doi.org/10.1002/dev.21850

Karb, R. A., Elliott, M. R., Dowd, J. B., \& Morenoff, J. D. (2012). Neighborhood-level stressors, social support, and diurnal patterns of cortisol: the Chicago Community Adult Health Study. Social science \& medicine, 75(6), 1038-1047. https://doi.org/10.1016/j.socscimed.2012.03.031

Katz, D. A., Harris, A., Abenavoli, R., Greenberg, M. T., \& Jennings, P. A. (2018). Educators' emotion regulation strategies and their physiological indicators of chronic stress over 1 year. Stress and Health: Journal of the International Society for the Investigation of Stress, 34(2), 278-285. https://doi.org/10.1002/smi.2782

Kennedy, D. P., \& Adolphs, R. (2012). The social brain in psychiatric and neurological disorders. Trends in cognitive sciences, 16(11), 559-572. https://doi.org/10.1016/j.tics.2012.09.006

Kidd, S. A., Corbett, B. A., Granger, D. A., Boyce, W. T., Anders, T. F., \& Tager, I. B. (2012). Daytime secretion of salivary cortisol and alpha-amylase in preschool-aged children with autism and

This article is protected by copyright. All rights reserved. 
typically developing children. Journal of autism and developmental disorders, 42(12), 2648-2658. https://dx.doi.org/10.1007\%2Fs10803-012-1522-z

*Kliewer, W., Riley, T., Zaharakis, N., Borre, A., Drazdowski, T. K., \& Jäggi, L. (2016). Emotion dysregulation, anticipatory cortisol, and substance use in urban adolescents. Personality and Individual Differences, 99, 200-205. https://doi.org/10.1016/j.tics.2012.09.006

Knack, J. M., Jensen-Campbell, L. A., \& Baum, A. (2011). Worse than sticks and stones? Bullying is associated with altered HPA axis functioning and poorer health. Brain and cognition, 77(2), 183190. https://doi.org/10.1016/j.bandc.2011.06.011

Knox, L., \& Douglas, J. (2009). Long-term ability to interpret facial expression after traumatic brain injury and its relation to social integration. Brain and Cognition, 69(2), 442-449. https://doi.org/10.1016/j.bandc.2008.09.009

Koizumi, M., \& Takagishi, H. (2014). The relationship between child maltreatment and emotion recognition. PLoS One, 9(1). https://dx.doi.org/10.1371\%2Fjournal.pone.0086093

Koss, K. J., \& Gunnar, M. R. (2018). Annual Research Review: early adversity, the hypothalamic-pituitaryadrenocortical axis, and child psychopathology. Journal of Child Psychology and Psychiatry, 59(4), 327-346. https://doi.org/10.1111/jcpp.12784

*Köther, U., Lincoln, T. M., \& Moritz, S. (2018). Emotion perception and overconfidence in errors under stress in psychosis. Psychiatry Research, 270, 981-991. https://doi.org/10.1016/j.psychres.2018.03.044

Kuras, Y. I., Assaf, N., Thoma, M. V., Gianferante, D., Hanlin, L., Chen, X., ... \& Rohleder, N. (2017). Blunted diurnal cortisol activity in healthy adults with childhood adversity. Frontiers in human neuroscience, 11, 574.https://doi.org/10.3389/fnhum.2017.00574

*Lane, J. D., Wellman, H. M., Olson, S. L., Miller, A. L., Wang, L., \& Tardif, T. (2013). Relations between temperament and theory of mind development in the United States and China: biological and behavioral correlates of preschoolers' false-belief understanding. Developmental Psychology, 49(5), 825-836. https://doi.org/10.1037/a0028825

Lang P. J., Bradley M. M., Cuthbert B. N. (2005): International Affective Picture System (IAPS): Affective Ratings of Pictures and Instruction Manual. Technical Report A-6. Gainesville, Florida: University of Florida.

Lam, S., Dickerson, S. S., Zoccola, P. M., \& Zaldivar, F. (2009). Emotion regulation and cortisol reactivity to a social-evaluative speech task. Psychoneuroendocrinology, 34(9), 1355-1362. https://doi.org/10.1016/j.psyneuen.2009.04.006

*Locke, R. L., Davidson, R. J., Kalin, N. H., \& Goldsmith, H. H. (2009). Children's context inappropriate anger and salivary cortisol. Developmental Psychology, 45(5), 1284-1297. https://doi.org/10.1037/a0015975

Lipsey, M. W., \& Wilson, D. B. (2001). Practical meta-analysis. Sage Publications, Inc.

Ma, S. T., Abelson, J. L., Okada, G., Taylor, S. F., \& Liberzon, I. (2017). Neural circuitry of emotion regulation: Effects of appraisal, attention, and cortisol administration. Cognitive, Affective, \& Behavioral Neuroscience, 17(2), 437-451. https://doi.org/10.3758/s13415-016-0489-1

Mayer, J. D., Salovey, P., Caruso, D. R., \& Sitarenios, G. (2003). Measuring emotional intelligence with the MSCEIT V2. 0. Emotion, 3(1), 97. https://doi.org/10.1037/1528-3542.3.1.97

This article is protected by copyright. All rights reserved. 
Mccann, S. J., Stewin, L. L., \& Short, R. H. (1991). Sex differences, social desirability, masculinity, and the tendency to worry. The Journal of genetic psychology, 152(3), 295-301.

https://doi.org/10.1080/00221325.1991.9914687

Mehta, U. M., Thirthalli, J., Basavaraju, R., Gangadhar, B. N., \& Pascual-Leone, A. (2014). Reduced mirror neuron activity in schizophrenia and its association with theory of mind deficits: evidence from a transcranial magnetic stimulation study. Schizophrenia bulletin, 40(5), 1083-1094. https://doi.org/10.1093/schbul/sbt155

*Mikolajczak, M., Roy, E., Luminet, O., Fillée, C., \& de Timary, P. (2007). The moderating impact of emotional intelligence on free cortisol responses to stress. Psychoneuroendocrinology, 32(8-10), 1000-1012. https://doi.org/10.1016/j.psyneuen.2007.07.009

Miller, G. E., Chen, E., \& Zhou, E. S. (2007). If it goes up, must it come down? Chronic stress and the hypothalamic-pituitary-adrenocortical axis in humans. Psychological bulletin, 133(1), 25. https://doi.org/10.1037/0033-2909.133.1.25

Miller, R., \& Plessow, F. (2013). Transformation techniques for cross-sectional and longitudinal endocrine data: application to salivary cortisol concentrations. Psychoneuroendocrinology, 38(6), 941-946. https://doi.org/10.1016/j.psyneuen.2012.09.013

*Miller, A. L., Song, J.-H., Sturza, J., Lumeng, J. C., Rosenblum, K., Kaciroti, N., \& Vazquez, D. M. (2017). Child cortisol moderates the association between family routines and emotion regulation in lowincome children. Developmental Psychobiology, 59(1), 99-110. https://doi.org/10.1002/dev.21471

Moher, D., Shamseer, L., Clarke, M., Ghersi, D., Liberati, A., Petticrew, M., ... \& Stewart, L. A. (2015). Preferred reporting items for systematic review and meta-analysis protocols (PRISMA-P) 2015 statement. Systematic reviews, 4(1), 1. https://doi.org/10.1186/2046-4053-4-1

Muscatello, R. A., \& Corbett, B. A. (2018). Comparing the effects of age, pubertal development, and symptom profile on cortisol rhythm in children and adolescents with autism spectrum disorder. Autism Research, 11(1), 110-120. https://doi.org/10.1002/aur.1879

Nicolson, N. A., \& van Diest, R. (2000). Salivary cortisol patterns in vital exhaustion. Journal of Psychosomatic Research, 49(5), 335-342. https://doi.org/10.1016/S0022-3999(00)00166-5

Nolte, T., Bolling, D. Z., Hudac, C., Fonagy, P., Mayes, L. C., \& Pelphrey, K. A. (2013). Brain mechanisms underlying the impact of attachment-related stress on social cognition. Frontiers in human neuroscience, 7, 816. https://doi.org/10.3389/fnhum.2013.00816

*Oberle, E. (2018). Social-emotional competence and early adolescents' peer acceptance in school: Examining the role of afternoon cortisol. PloS one, 13(2), e0192639. https://doi.org/10.1371/journal.pone.0192639

Ochsner, K. N. (2008). The social-emotional processing stream: five core constructs and their translational potential for schizophrenia and beyond. Biological psychiatry, 64(1), 48-61. https://doi.org/10.1016/j.biopsych.2008.04.024

Otto, L. R., Sin, N. L., Almeida, D. M., \& Sloan, R. P. (2018). Trait emotion regulation strategies and diurnal cortisol profiles in healthy adults. Health Psychology: Official Journal of the Division of Health Psychology, American Psychological Association, 37(3), 301-305. https://doi.org/10.1037/hea0000564

This article is protected by copyright. All rights reserved. 
Palmer, B. R., \& Stough, C. (2001). Swinburne university emotional intelligence test: Interim technical manual. Melbourne: Swinburne University.

*Pascual-Sagastizabal, E., Del Puerto, N., Cardas, J., Sánchez-Martín, J. R., Vergara, A. I., \& Azurmendi, A. (2019). Testosterone and cortisol modulate the effects of empathy on aggression in children. Psychoneuroendocrinology, 103, 118-124. https://doi.org/10.1016/j.psyneuen.2019.01.014

Perner, J., Leekam, S. R., \& Wimmer, H. (1987). Three-year-olds' difficulty with false belief: The case for a conceptual deficit. British journal of developmental psychology, 5(2), 125-137. https://doi.org/10.1111/j.2044-835X.1987.tb01048.x

Petrides, K. V., \& Furnham, A. (2003). Trait emotional intelligence: Behavioural validation in two studies of emotion recognition and reactivity to mood induction. European Journal of Personality, 17, 39-57. https://doi.org/10.1002/per.466

Ping, J., Lei, Y. Y., Liu, L., Wang, T. T., Feng, Y. H., \& Wang, H. (2012). Inheritable stimulatory effects of caffeine on steroidogenic acute regulatory protein expression and cortisol production in human adrenocortical cells. Chemico-biological interactions, 195(1), 68-75. https://doi.org/10.1016/j.cbi.2011.11.001

Plana, I., Lavoie, M. A., Battaglia, M., \& Achim, A. M. (2014). A meta-analysis and scoping review of social cognition performance in social phobia, posttraumatic stress disorder and other anxiety disorders. Journal of Anxiety Disorders, 28, 169-177. https://doi.org/10.1016/j.janxdis.2013.09.005

Putnam, S. K., Lopata, C., Thomeer, M. L., Volker, M. A., \& Rodgers, J. D. (2015). Salivary cortisol levels and diurnal patterns in children with autism spectrum disorder. Journal of Developmental and Physical Disabilities, 27(4), 453-465. https://doi.org/10.1007/s10882-015-9428-2

Putman, P., \& Roelofs, K. (2011). Effects of single cortisol administrations on human affect reviewed: Coping with stress through adaptive regulation of automatic cognitive processing. Psychoneuroendocrinology, 36(4), 439-448. https://doi.org/10.1016/j.psyneuen.2010.12.001

Quirin, M., Kuhl, J., \& Düsing, R. (2011). Oxytocin buffers cortisol responses to stress in individuals with impaired emotion regulation abilities. Psychoneuroendocrinology, 36(6), 898-904. https://doi.org/10.1016/j.psyneuen.2010.12.005

Rich, B. A., Grimley, M. E., Schmajuk, M., Blair, K. S., Blair, R. J. R., \& Leibenluft, E. (2008). Face emotion labeling deficits in children with bipolar disorder and severe mood dysregulation. Development and psychopathology, 20(2), 529-546. https://doi.org/10.1017/S0954579408000266

Richards, J. M., \& Gross, J. J. (1999). Composure at any cost? The cognitive consequences of emotion suppression. Personality and Social Psychology Bulletin, 25(8), 1033-1044. https://doi.org/10.1177/01461672992511010

Romeo, R. D., Lee, S. J., \& McEwen, B. S. (2004). Differential stress reactivity in intact and ovariectomized prepubertal and adult female rats. Neuroendocrinology, 80(6), 387-393. https://doi.org/10.1159/000084203

Ruiz-Robledillo, N., \& Moya-Albiol, L. (2014). Emotional intelligence modulates cortisol awakening response and self-reported health in caregivers of people with autism spectrum disorders. Research in Autism Spectrum Disorders, 8(11), 1535-1543. https://doi.org/10.1016/j.rasd.2014.08.003

This article is protected by copyright. All rights reserved. 
Schmidt, F., \& Hunter, J. (2015). Methods of meta-analysis : Correcting error and bias in research findings / Frank L. Schmidt, John E. Hunter. (3rd ed.).

Schmidt, F. L., Oh, I. S., \& Hayes, T. L. (2009). Fixed-versus random-effects models in meta-analysis: Model properties and an empirical comparison of differences in results. British Journal of Mathematical and Statistical Psychology, 62(1), 97-128. https://doi.org/10.1348/000711007X255327

Schwartz, E. B., Granger, D. A., Susman, E. J., Gunnar, M. R., \& Laird, B. (1998). Assessing salivary cortisol in studies of child development. Child development, 69(6), 1503-1513. https://doi.org/10.1111/j.1467-8624.1998.tb06173.x

Segrin, C., McNelis, M., \& Swiatkowski, P. (2016). Social skills, social support, and psychological distress: A test of the social skills deficit vulnerability model. Human Communication Research, 42(1), 122 137. https://doi.org/10.1111/hcre.12070

Shakoor, S., Jaffee, S. R., Bowes, L., Ouellet-Morin, I., Andreou, P., Happé, F., ... \& Arseneault, L. (2012). A prospective longitudinal study of children's theory of mind and adolescent involvement in bullying. Journal of Child Psychology and Psychiatry, 53(3), 254-261. https://doi.org/10.1111/j.1469-7610.2011.02488.x

Shields, A., \& Cicchetti, D. (1997). Emotion regulation among school-age children: The development and validation of a new criterion Q-sort scale. Developmental psychology, 33(6), 906. https://doi.org/10.1037/0012-1649.33.6.906

*Shields, G. S., Kuchenbecker, S. Y., Pressman, S. D., Sumida, K. D., \& Slavich, G. M. (2016). Better cognitive control of emotional information is associated with reduced pro-inflammatory cytokine reactivity to emotional stress. Stress, 19(1), 63-68. https://doi.org/10.3109/10253890.2015.1121983

Shields, G. S., Moons, W. G., \& Slavich, G. M. (2017). Inflammation, self-regulation, and health: An immunologic model of self-regulatory failure. Perspectives on Psychological Science, 12(4), 588612. https://doi.org/10.1177/1745691616689091

*Smeets, T., Dziobek, I., \& Wolf, O. T. (2009). Social cognition under stress: differential effects of stressinduced cortisol elevations in healthy young men and women. Hormones and Behavior, 55(4), 507-513. https://doi.org/10.1016/j.yhbeh.2009.01.011

Sterne, J. A., Egger, M., \& Moher, D. (2008). Addressing reporting biases. Cochrane handbook for systematic reviews of interventions: Cochrane book series, 297-333. https://doi.org/10.1002/9780470712184.ch10

Tellegen, A. (1982). Brief manual for the Differential Personality Questionnaire. Unpublished manuscript, University of Minnesota, Minneapolis

Trickett, P. K., Noll, J. G., Susman, E. J., Shenk, C. E., \& Putnam, F. W. (2010). Attenuation of cortisol across development for victims of sexual abuse. Development and psychopathology, 22(1), 165-175. https://doi.org/10.1017/\$0954579409990332

*Tomova, L., von Dawans, B., Heinrichs, M., Silani, G., \& Lamm, C. (2014). Is stress affecting our ability to tune into others? Evidence for gender differences in the effects of stress on self-other distinction. Psychoneuroendocrinology, 43, 95-104. https://doi.org/10.1016/j.psyneuen.2014.02.006

*van Honk, J., Tuiten, A., van den Hout, M., Koppeschaar, H., Thijssen, J., de Haan, E., \& Verbaten, R. (2000). Conscious and preconscious selective attention to social threat: different neuroendocrine

This article is protected by copyright. All rights reserved. 
response patterns. Psychoneuroendocrinology, 25(6), 577-591. https://doi.org/10.1016/S03064530(00)00011-1

Viau, V. (2002). Functional cross-talk between the hypothalamic-pituitary-gonadal and-adrenal axes. Journal of neuroendocrinology, 14(6), 506-513. https://doi.org/10.1046/j.13652826.2002.00798.x

Villanueva, L., Montoya-Castilla, I., \& Prado-Gascó, V. (2017). The importance of trait emotional intelligence and feelings in the prediction of perceived and biological stress in adolescents: hierarchical regressions and fsQCA models. Stress, 20(4), 355-362.

https://doi.org/10.1080/10253890.2017.1340451

Vrshek-Schallhorn, S., Avery, B. M., Ditcheva, M., \& Sapuram, V. R. (2018). The cortisol reactivity threshold model: Direction of trait rumination and cortisol reactivity association varies with stressor severity. Psychoneuroendocrinology, 92, 113-122. https://doi.org/10.1016/j.psyneuen.2017.11.002

*Wilbraham, S. J., Qualter, P., \& Roy, M. P. (2018). Emotional intelligence and cortisol responses: Can laboratory findings be replicated in classrooms and using other El measures? Personality and Individual Differences, 120, 58-64. https://doi.org/10.1016/j.paid.2017.08.021

Wimmer, H., \& Perner, J. (1983). Beliefs about beliefs: Representation and constraining function of wrong beliefs in young children's understanding of deception. Cognition, 13(1), 103-128. https://doi.org/10.1016/0010-0277(83)90004-5

Yu, C. L., \& Chou, T. L. (2018). A dual route model of empathy: A neurobiological prospective. Frontiers in psychology, 9, 2212. https://dx.doi.org/10.3389\%2Ffpsyg.2018.02212

*Zilioli, S., Ponzi, D., Henry, A., \& Maestripieri, D. (2015). Testosterone, Cortisol and Empathy: Evidence for the Dual-Hormone Hypothesis. 1(4)). https://doi.org/10.1007/s40750-014-0017-x

This article is protected by copyright. All rights reserved. 


\section{Tables}

Table 1

Guidelines for the calculation of effect sizes.

\begin{tabular}{ll}
\hline Study description & Decision \\
\hline $\begin{array}{l}\text { Longitudinal studies in which only cross- } \\
\text { sectional baseline data were relevant }\end{array}$ & Studies were coded as cross-sectional \\
\hline $\begin{array}{l}\text { Experimental studies in which only cross- } \\
\text { sectional baseline data were relevant }\end{array}$ & Studies were coded as cross-sectional \\
\end{tabular}

Studies that measured multiple domains Effects sizes for each core social cognition
of social cognition in the same sample domain were extracted as independent effect sizes; effect sizes for each sub-domain of core social cognition were combined as one effect size in the main analysis but treated as independent effect sizes in subgroup analysis

\begin{tabular}{ll}
\hline $\begin{array}{l}\text { Studies that calculated effect sizes for } \\
\text { social cognition subscale scores and } \\
\text { overall scale scores }\end{array}$ & $\begin{array}{l}\text { Effect sizes for general social cognition we } \\
\text { prioritized }\end{array}$ \\
\hline $\begin{array}{l}\text { Studies that calculated effect sizes for } \\
\text { social cognition subscales }\end{array}$ & $\begin{array}{l}\text { An average effect size was computed to } \\
\text { represent the effect size for general social } \\
\text { cognition }\end{array}$
\end{tabular}

Studies that reported separate results for Effects sizes for each sample were combined as different populations (e.g., men vs. one effect size for each study, but extracted as women), cortisol measured at different independent effect sizes in subgroup analysis time points.

$\begin{array}{ll}\text { Studies that measured cortisol at several } & \text { Effect size for cortisol half an hour post } \\ \text { time-points in the morning } & \text { awakening was prioritized }\end{array}$

Table 2

Included studies and descriptive variables

\begin{tabular}{|c|c|c|c|c|c|c|c|}
\hline Study & $\mathbf{N}$ & Males\% & $\begin{array}{c}\text { Average } \\
\text { (median) } \\
\text { age } \\
\text { (years) }\end{array}$ & $\begin{array}{l}\text { Collection } \\
\text { time of } \\
\text { cortisol } \\
\text { samples }\end{array}$ & $\begin{array}{l}\text { Fastin } \\
\mathbf{g} \\
\text { instru } \\
\text { ctions }\end{array}$ & $\begin{array}{c}\text { Social cognition } \\
\text { domain }\end{array}$ & Measures \\
\hline $\begin{array}{l}\text { Bechtoldt et al. } \\
(2016)\end{array}$ & 166 & 100 & $\begin{array}{l}\text { College } \\
\text { students }\end{array}$ & Afternoon & Yes & $\begin{array}{l}\text { Emotion } \\
\text { recognition, } \\
\text { empathy and } \\
\text { emotion control }\end{array}$ & $\begin{array}{l}\text { Emotion recognition, } \\
\text { understand and } \\
\text { management subscales of } \\
\text { MSCEIT V2.0 }\end{array}$ \\
\hline $\begin{array}{l}\text { Brandtstädter et } \\
\text { al. (1991) }\end{array}$ & 767 & 50 & 45 & $\begin{array}{l}\text { Morning \& } \\
\text { afternoon }\end{array}$ & No & Emotion control & $\begin{array}{l}\text { Emotion lability subscale of } \\
\mathrm{FPI}\end{array}$ \\
\hline $\begin{array}{l}\text { England-Mason } \\
\text { et al. (2017) }\end{array}$ & 118 & 0 & 32 & $\begin{array}{c}\text { Across the } \\
\text { day }\end{array}$ & Yes & Emotion control & $\begin{array}{l}\text { DERS; emotion suppress } \\
\text { subscale of ERC }\end{array}$ \\
\hline Fox et al. (2010) & 104 & 100 & 22 & Morning & No & Emotion control & Visual Probe tasks \\
\hline
\end{tabular}

This article is protected by copyright. All rights reserved. 


\begin{tabular}{|c|c|c|c|c|c|c|c|}
\hline $\begin{array}{l}\text { Gonzalez- } \\
\text { Liencreset al. } \\
(2016)\end{array}$ & 52 & 52 & 24 & Afternoon & No & Empathy & $\begin{array}{l}\text { Empathic concern and } \\
\text { perspective taking subscales } \\
\text { of IRI }\end{array}$ \\
\hline $\begin{array}{l}\text { Kliewer et al. } \\
(2016)\end{array}$ & 229 & 41 & 12 & $\begin{array}{c}\text { Across the } \\
\text { day }\end{array}$ & Yes & Emotion control & ERC \\
\hline $\begin{array}{l}\text { Köther et al. } \\
(2018)\end{array}$ & 14 & 61 & 36 & Afternoon & Yes & $\begin{array}{l}\text { Emotion } \\
\text { recognition }\end{array}$ & $\begin{array}{l}\text { The emotion perception and } \\
\text { confidence task adapted } \\
\text { from RMET }\end{array}$ \\
\hline $\begin{array}{l}\text { Lane et al. } \\
\text { (2013) }\end{array}$ & 102 & 50 & 4 & $\begin{array}{l}\text { Across the } \\
\text { day }\end{array}$ & No & Empathy & False-belief tasks \\
\hline $\begin{array}{l}\text { Locke et al. } \\
\text { (2009) }\end{array}$ & 291 & 51 & 8 & Morning & Yes & Emotion control & Context inappropriate anger \\
\hline $\begin{array}{l}\text { Mikolajczak et } \\
\text { al. (2007) }\end{array}$ & 28 & 50 & 20 & Afternoon & Yes & $\begin{array}{l}\text { Emotion control } \\
\text { Empathy }\end{array}$ & $\begin{array}{l}\text { Self-control and emotional } \\
\text { sensitivity subscales of TEIQ }\end{array}$ \\
\hline $\begin{array}{l}\text { Miller et al. } \\
(2017)\end{array}$ & 380 & 50 & 4 & Morning & No & Emotion control & $\begin{array}{l}\text { Negative liability subscales } \\
\text { of ERC }\end{array}$ \\
\hline Oberle (2018) & 154 & 54 & 11 & Afternoon & Yes & Empathy & $\begin{array}{l}\text { Perspective taking subscale } \\
\text { of IRI }\end{array}$ \\
\hline $\begin{array}{l}\text { Pascual- } \\
\text { Sagastizabal et } \\
\text { al. (2019) }\end{array}$ & 159 & 50 & 8 & Morning & No & Empathy & $\begin{array}{l}\text { Empathy quotient-children } \\
\text { version }\end{array}$ \\
\hline $\begin{array}{l}\text { Shields et al. } \\
(2016)\end{array}$ & 36 & 0 & 19 & Afternoon & No & Emotion control & Emotional Stroop task \\
\hline $\begin{array}{l}\text { Smeets et al. } \\
(2009)\end{array}$ & 64 & 50 & 26 & Morning & Yes & $\begin{array}{l}\text { Emotion } \\
\text { recognition and } \\
\text { empathy }\end{array}$ & RMET; MASC \\
\hline $\begin{array}{l}\text { Tomova et al. } \\
(2014)\end{array}$ & 64 & 50 & 29 & Afternoon & No & $\begin{array}{l}\text { Emotion } \\
\text { recognition; } \\
\text { empathy }\end{array}$ & RMET; IRI; EC \\
\hline $\begin{array}{l}\text { Van Honk et al. } \\
(2000)\end{array}$ & 20 & 100 & 23 & Afternoon & No & Emotion control & Emotion Stroop task \\
\hline $\begin{array}{l}\text { Wilbraham et al. } \\
(2018)\end{array}$ & 89 & 23 & 19 & Afternoon & No & $\begin{array}{l}\text { Emotion } \\
\text { recognition, } \\
\text { empathy and } \\
\text { emotion control }\end{array}$ & $\begin{array}{l}\text { Emotion recognition, } \\
\text { understand and } \\
\text { management subscales of } \\
\text { SUEIT }\end{array}$ \\
\hline $\begin{array}{l}\text { Zilioli et al. } \\
\text { (2015) }\end{array}$ & 453 & 70 & 29 & Afternoon & No & $\begin{array}{l}\text { Emotion } \\
\text { recognition, } \\
\text { empathy }\end{array}$ & $\begin{array}{l}\text { RMET; Empathic concern } \\
\text { and perspective taking } \\
\text { subscales of IRI }\end{array}$ \\
\hline
\end{tabular}

Note. Miller et al. (2017): the sampling time of cortisol was before breakfast, though no more information was provided. Measurements of social cognition: MSCEIT= Mayer-Salovey-Caruso Emotional Intelligence Test (Mayer et al., 2003); ERC = Emotion Regulation Checklist (Shields \& Cicchetti, 1997); DERS = Difficulties in Emotion Regulation Scale (Gratz \& Roemer, 2004); FPI = Freiburg Personality Inventory (Fahrenbekc, Hampel, \& Selg, 1973); MPQ = Tellegen's Multidimensional Personality Questionnaire (Tellegen, 1982); TEIQ = Trait EI Questionnaire (Petrides \& Furnham, 2003); SUEIT = Swinburne University Emotional Intelligence Test (Palmer \& Stough, 2001); RMET = Reading the Mind in the Eyes Test (Baron-Cohen et al., 2001); IRI = Interpersonal Reactivity Index (Davis, 1983); EC = Emotion Contagion Scale (Doherty, 1997); MASC = Movie for the Assessment of Social Cognition (Dziobek et al., 2006); Emotion Stroop task in van Honk et al (2000) used pictures of Facial Affect and other comparable specially prepared facial stimuli from Ekman and Friesen's (1976); Visual Probe tasks in Fox et al. (2010) used pictures from the International Affective Picture System (Lang, Bradley, \& Cuthbert, 2005); False-belief tasks in Lane et al. (2013) are unexpected-contents task (Perner, Leekam, \& Wimmer, 1987) and switched-location task (Wimmer \& Perner, 1983).

Table 3

Meta-Analytic Results for the Relationship between Emotion Control and Cortisol Concentration

This article is protected by copyright. All rights reserved. 


\begin{tabular}{|c|c|c|c|c|c|c|c|c|c|}
\hline \multirow{2}{*}{ Characteristics } & \multirow{2}{*}{$\mathbf{k}$} & \multirow{2}{*}{$\mathbf{N}$} & \multirow{2}{*}{$\bar{r}$} & \multirow{2}{*}{$\mathbf{P}$} & \multirow{2}{*}{ SDp } & \multirow{2}{*}{ SEp } & \multirow{2}{*}{$95 \% \mathrm{Cl}$} & \multicolumn{2}{|c|}{ heterogeneity } \\
\hline & & & & & & & & $Q^{\alpha}$ & $I^{2}(\%)$ \\
\hline Total set & 11 & 2229 & .075 & $.083^{*}$ & .074 & .023 & $(.033, .132)$ & 11.13 & 10.2 \\
\hline \multicolumn{10}{|l|}{$\begin{array}{l}\text { Sampling time of } \\
\text { cortisol }\end{array}$} \\
\hline Morning & 4 & 1542 & .085 & $.085^{*}$ & .050 & .025 & $(.006, .164)$ & 2.859 & 0 \\
\hline (After)noon & 6 & 1106 & .023 & .025 & .063 & .026 & $(-.041, .092)$ & 3.580 & 0 \\
\hline Non-specific & 2 & 348 & .142 & .169 & .109 & .077 & $(-.813,1.15)$ & 2.188 & 54.2 \\
\hline \multicolumn{10}{|l|}{ Sex } \\
\hline Males & 7 & 941 & .081 & $.086 *$ & .085 & .032 & $(.007, .164)$ & 5.766 & 0 \\
\hline Females & 5 & 819 & .061 & .070 & .111 & .050 & $(-.068, .209)$ & 8.132 & 50.8 \\
\hline Mixed & 2 & 469 & .088 & .088 & .064 & .045 & $(-.486, .662)$ & 0.965 & 0 \\
\hline \multicolumn{10}{|l|}{ Age } \\
\hline Children & 1 & 380 & .110 & $.121 *$ & - & .051 & $(.022, .220)$ & - & - \\
\hline Adolescents & 2 & 521 & .129 & .145 & .100 & .071 & $(-.753,1.04)$ & 2.674 & 62.6 \\
\hline Young adults & 6 & 443 & .033 & .038 & .107 & .044 & $(-.074, .150)$ & 4.124 & 0 \\
\hline $\begin{array}{l}\text { Middle-aged \& } \\
\text { older adults }\end{array}$ & 2 & 885 & .050 & $.052 *$ & .005 & .004 & $(.003, .100)$ & 0.013 & 0 \\
\hline $\begin{array}{l}\text { Cortisol data } \\
\text { transformed? }\end{array}$ & & & & & & & & & \\
\hline No & 3 & 152 & .035 & .039 & .197 & .114 & $(-.451, .529)$ & 3.817 & 47.6 \\
\hline Yes & 8 & 2077 & .078 & $.086^{*}$ & .062 & .022 & $(.034, .137)$ & 6.621 & 0 \\
\hline \multicolumn{10}{|l|}{ Fasting? } \\
\hline No & 6 & 1396 & .058 & .061 & .063 & .026 & $(-.005, .127)$ & 4.564 & 0 \\
\hline Yes & 5 & 833 & .104 & $.119 *$ & .085 & .038 & $(.013, .224)$ & 4.896 & 18.3 \\
\hline
\end{tabular}

Note. $\mathrm{k}=$ number of correlations; $\mathrm{n}=$ combined sample size; $r=$ mean uncorrected correlation; $\rho=$ estimated true score correlation corrected for measurement error; $\mathrm{SD}_{\rho}=$ observed standard deviation of corrected correlations; $\mathrm{SE}_{\rho}=\mathrm{Standard}$ error of corrected correlations; $95 \% \mathrm{Cl}=95 \%$ confidence interval for $\rho ; Q=Q$-test statistic for test of heterogeneity in true score correlations. ${ }^{*} \rho=$ significant effect sizes.

Table 4

Summary of Studies on Social Cognition and Diurnal Cortisol Rhythm

\begin{tabular}{|c|c|c|c|c|c|c|}
\hline Study & $\begin{array}{l}\text { Study } \\
\text { design }\end{array}$ & Sample & Saliva cortisol sampling & $\begin{array}{l}\text { Cortisol } \\
\text { measure }\end{array}$ & $\begin{array}{l}\text { Social cognition } \\
\text { domain } \\
\text { (measures) }\end{array}$ & Main findings \\
\hline $\begin{array}{l}\text { Johnson et } \\
\text { al., } 2014\end{array}$ & $\begin{array}{l}\text { Cross- } \\
\text { sectional }\end{array}$ & $\begin{array}{l}57 \text { adults } \\
\text { (Mage }=19, \\
56 \% \text { males) }\end{array}$ & $\begin{array}{l}\text { At awakening and } 30 \mathrm{~min} \\
\text { after awakening for one day. }\end{array}$ & CAR & Empathy (IRI) & $\begin{array}{l}\text { Better affective } \\
\text { empathy was } \\
\text { associated with greater } \\
\text { CAR. Cognitive empathy } \\
\text { was not associated with } \\
\text { CAR. }\end{array}$ \\
\hline Katz et al., & Longitudi & 29 adults & At awakening, $30 \mathrm{~min}$ after & Morning & Emotion control & Emotional control was \\
\hline
\end{tabular}

2018 nal (Mage $=45$, awakening, before lunch, and cortisol; CAR (ERQ) not associated with

$17.2 \%$ at bedtime for one day at cortisol at awakening or males) each of three waves (in the CAR over the year.

October of year 1 and the March and October of year 2)

Locke et Cross- 292 children Within half an hour after Morning

al., 2009 sectional (M age $=8.3$ awakening, at 4 p.m., and at cortisol; years, $48 \%$ bedtime for three days. diurnal boys) inappropriate (context Poorer emotion contro was associated with a lower morning cortisol and flatter diurnal cortisol slope. Sexspecific analysis showed

This article is protected by copyright. All rights reserved. 


\begin{tabular}{|c|c|c|c|c|c|c|}
\hline & & & & & & $\begin{array}{l}\text { this association was } \\
\text { only significant in boys. }\end{array}$ \\
\hline $\begin{array}{l}\text { Miller et } \\
\text { al., } 2017\end{array}$ & $\begin{array}{l}\text { Cross- } \\
\text { sectional }\end{array}$ & $\begin{array}{l}380 \text { children } \\
\text { ( } \mathrm{M} \text { age }= \\
4.2,50 \% \\
\text { boys) }\end{array}$ & $\begin{array}{l}\text { At } 1.5 \text { hours after awakening, } \\
\text { before lunch and in the } \\
\text { afternoon for three days. }\end{array}$ & $\begin{array}{l}\text { Morning } \\
\text { cortisol; } \\
\text { diurnal } \\
\text { cortisol slope }\end{array}$ & $\begin{array}{l}\text { Emotion control } \\
\text { (ERC) }\end{array}$ & $\begin{array}{l}\text { Emotional control was } \\
\text { not associated with } \\
\text { diurnal cortisol slope. }\end{array}$ \\
\hline $\begin{array}{l}\text { Otto, Sin, } \\
\text { \& Almeida, } \\
2018\end{array}$ & $\begin{array}{l}\text { Cross- } \\
\text { sectional }\end{array}$ & $\begin{array}{l}46 \text { adults } \\
\text { (Mage }=54, \\
50 \% \text { males), }\end{array}$ & $\begin{array}{l}\text { At awakening, } 30 \text { min after } \\
\text { awakening, before lunch, and } \\
\text { at bedtime for four days. }\end{array}$ & $\begin{array}{l}\text { CAR; diurnal } \\
\text { cortisol slope; } \\
\text { AUC }\end{array}$ & $\begin{array}{l}\text { Emotion control } \\
\text { (ERQ) }\end{array}$ & $\begin{array}{l}\text { Better emotion control } \\
\text { was associated with } \\
\text { greater CAR and } \\
\text { marginally flatter } \\
\text { diurnal cortisol slope } \\
\text { ( } p=.08 \text { ), but was not } \\
\text { associated with AUC. }\end{array}$ \\
\hline
\end{tabular}

Note: $\mathrm{AUC}=$ area under the curve, total daily cortisol; IRI = Interpersonal Reactivity Index (Davis, 1983); ERQ = Emotion Regulation Questionnaire (Gross \& John, 2003); ERC = Emotion Regulation Checklist (Shields \&

Cicchetti, 1997)

This article is protected by copyright. All rights reserved. 


\section{Figure legends}

\section{Figure 1 PRISMA Diagram}

Figure 2 Forest plot of studies examining the relationship between emotion control and cortisol levels in general population samples

Figure 3 Forest plot of studies examining the relationship between empathy and cortisol levels in general population samples

Figure 4 Forest plot of studies examining the relationship between emotion recognition and cortisol levels in general population samples

Figure 5 Funnel plots of studies for emotion control, empathy and emotion recognition (respectively, from left to right)

This article is protected by copyright. All rights reserved. 


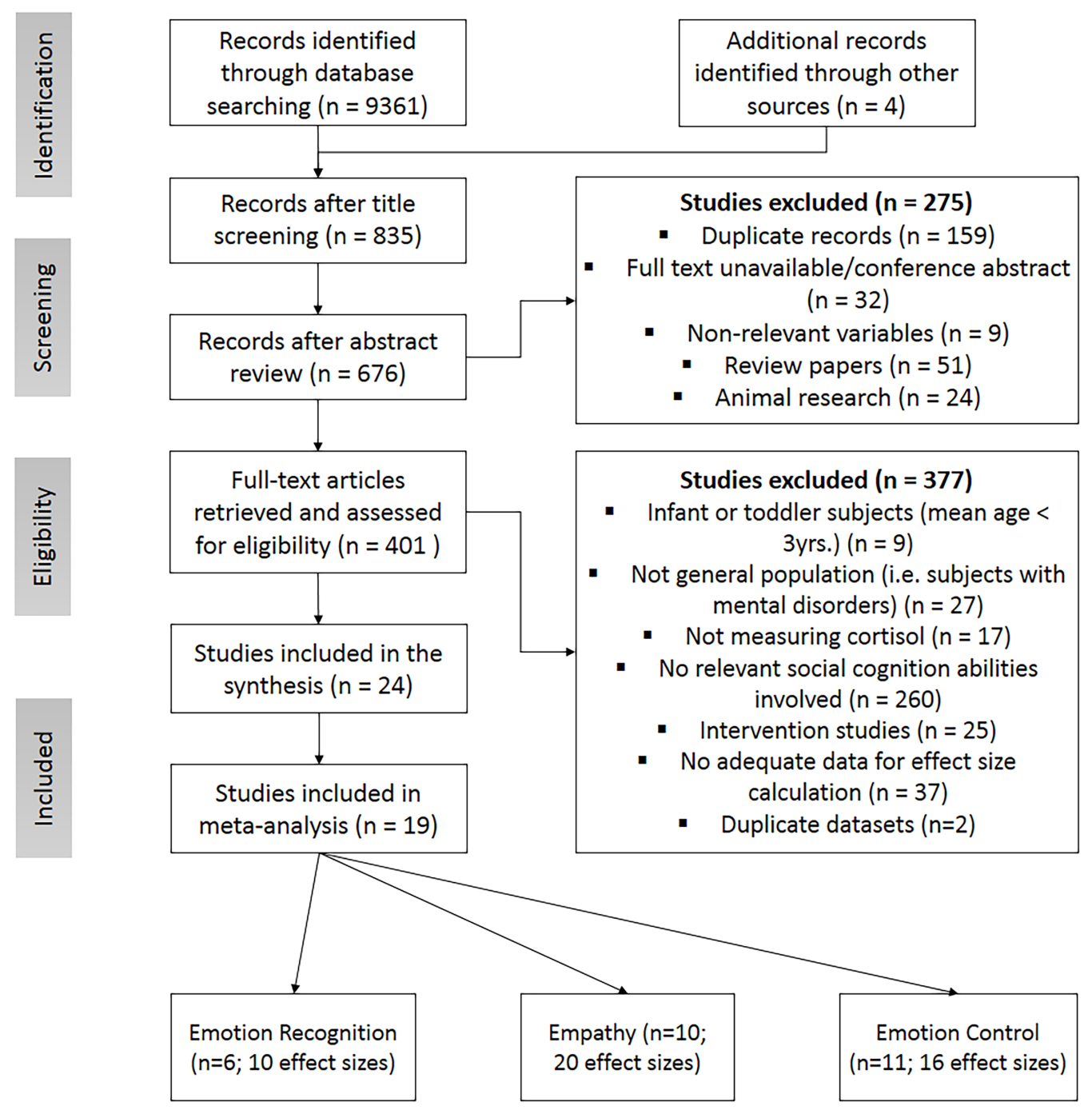

This article is protected by copyright. All rights reserved. 


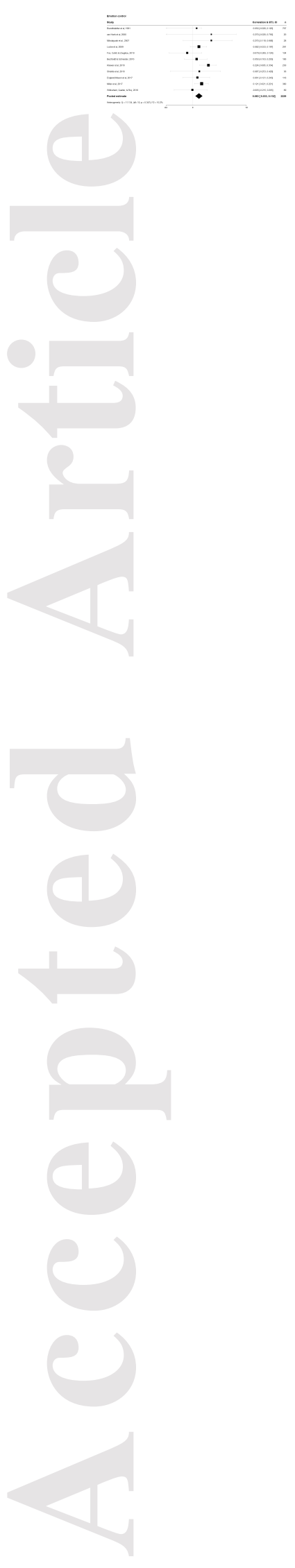

This article is protected by copyright. All rights reserved. 


$$
\equiv \quad \vdots \vdots \equiv
$$
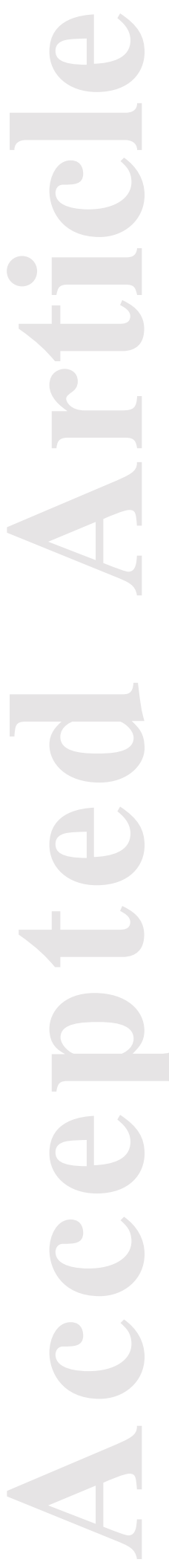

This article is protected by copyright. All rights reserved. 


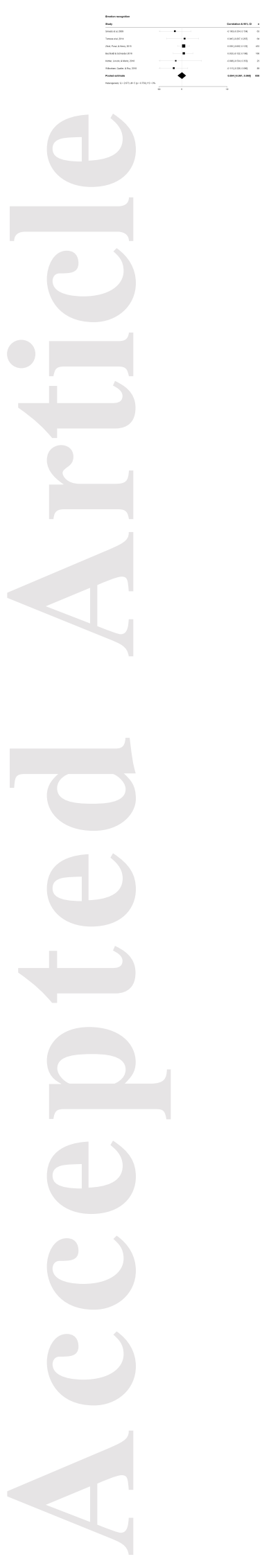

This article is protected by copyright. All rights reserved. 

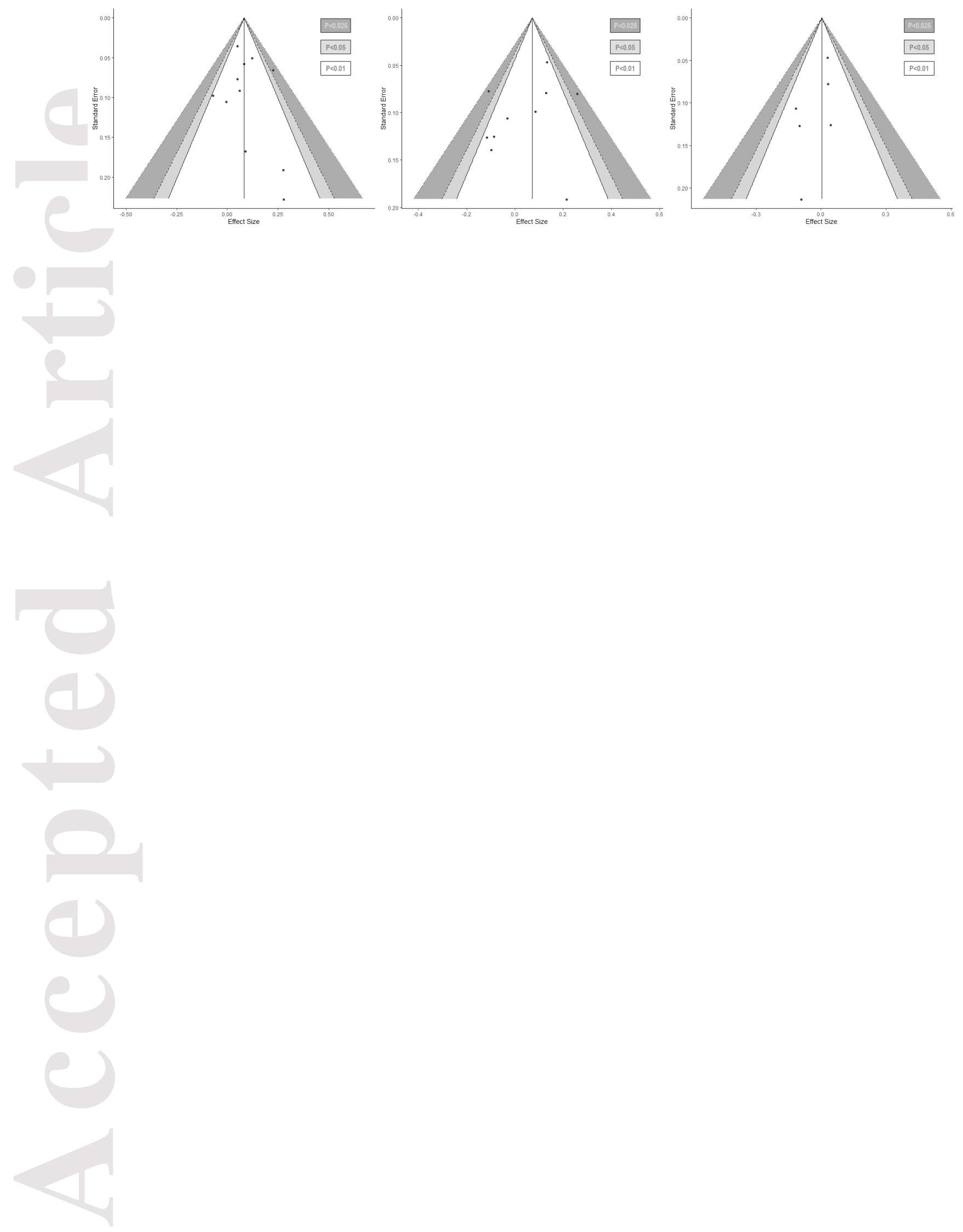

This article is protected by copyright. All rights reserved. 